\title{
Mental Health among Government School Teachers
}

\author{
Chanderkant Gorsy ${ }^{1 *}$, Neeraj Panwar ${ }^{1}$, Sandeep Kumar $^{1}$
}

\section{ABSTRACT}

Teaching is being considered as one of the noblest profession since ancient times. With the changing socio-economic scenario and increasing unemployment, the values of teachers' and their professional concern with the job have forcibly undergone a drastic change which adversely affects their mental health. The level of mental health of a teacher has been found affected with numerous personal as well as professional demands. Health of teachers, on social, physical and mental health domains adds to the efficiency not only to their professional growth and development but also to their personality. Moreover, they have also been considered as the constructors of the future of a country. Keeping these facts into the consideration, present study aimed to access the level of personal mental health of school teachers, particularly those who work in the public sector schools. Survey method has been employed and Mental Health Index (MHI) was used for collecting the data. 100 secondary and higher secondary school teachers were included in the study. The data was analyzed using descriptive analysis and to find the differences for gender and locations t- test was applied. The t-values reveals that significant gender differences exist among government school teachers and male school teachers were found better on mental health than their female counterparts. Additionally, teachers posted at schools located under urban area were found higher on mental health as compared to teaches posted at schools located under rural areas.

Keywords: Mental health, Gender, school teachers Urban, Rural

Schools are not the places where students went to study but they are being considered as the temple of education where teachers play similar role being observed by the priest of any religious place. Performance of the school is the collective team work of teachers as well as students. Teachers not only impart education to the students but also act as a bridge to fill the gap between students, principal, management and parents. Their cordial relation with students reflects in the behavior and speech of teachers. Sound professional relations of a teacher with students, their parents, colleagues, and management may lead to their better mental health.

In the present world of professional competence everyone is threatened by increasing competitions and degraded circumstances. Health is and has been always one of the most important areas where focus is necessary for all times. Resultantly the concept of health has been

\footnotetext{
${ }^{1}$ Ph.D, Research scholar, Department of Psychology, Maharshi Dayanand University, Rohtak (Haryana)

*Responding Author

(C) 2015 I C Gorsy, N Panwar, S Kumar; licensee IJIP. This is an Open Access Research distributed under the terms of the Creative Commons Attribution License (http://creativecommons.org/licenses/by/2.0), which permits unrestricted use, distribution, and reproduction in any Medium, provided the original work is properly cited.
} 
extended beyond the proper functioning of the body; it includes controlled emotions, a sound and efficient mind. In simple words it means that mind and body both are working efficiently and harmoniously (Kaur, 2007).

It is evident from the previous researches that mental health plays a pivot and vital role in human life. It is not only important but essential for survival as a social being. No area of human life is beyond the range of mental health. It includes every aspect and dimension of human personality and the individual's adjustment to own self, others and environment. The main characteristic of mental health is adjustment, magnitude of which decides the status of mental health. The greater the degree of adjustment, the greater will be the mental health and lesser degree will lead to the lesser mental health. The mentally healthy individual can adapt him or herself to every best and worst condition of life and environment. The expression 'Mental Health 'consists of two words-

The word 'mental' usually implies something more than purely cerebral functioning of a person. It includes one's emotional affective states. It is the equilibrium in one's Sociocultural context that is reflected by the relationship one establishes with others.

Similarly, 'health' refers to more than physical wellbeing. It also connotes the individual's intraphysic balance, the interaction of one's physic-structure with the external and social environment (Kaur, 2007). For example, a person who is academically sound and also knows what is to be taught but at times is not able to impart it due to certain factors of adjustment with his/her environment.

Mental health stands for the health of the mind, "The wholesomeness of mind"- analogous to the wholesomeness of the body as implicit in physical health. Accordingly, mental health is concerned with the health of one's mind and its functioning in the same way as the physical health is concerned with the health of one's physical organs and their functioning.

Mental health, in layman terms, is a level of psychological well-being, or an absence of a mental disorder (Singh, 2004). From the perspective of positive psychology or holism, mental health may include an individual's ability to enjoy life, and create a balance between life activities and efforts to achieve psychological resilience. According to World Health Organization (WHO) mental health includes "subjective well-being, perceived self-efficacy, autonomy, competence, intergenerational dependence, and self-actualization of one's intellectual and emotional potential, among others.

Kornhauser (1965) connotes that mental health includes those behaviors, perceptions and feelings that determine a person's overall level of personal effectiveness, success, happiness and excellence of functioning as a person. It depends on the development and retention of goals that is neither too high nor too low to permit realistic successful maintenance of belief in one's self as a worthy, effective human being. Further, it is the condition in which the individual manifest 
through self-evaluation, adjustability, maturity, regular life, absence of extremism satisfactory social adjustment and satisfaction from his chief occupation. Complete mental health is an ideal. Any individual who possesses the greatest number of these qualities will be nearest the ideal (Singh, Chandra \& Parihar, 2011).

Singh and Gupta (1983) described six indices of mental health i.e. emotional stability (experiencing subjective stable feeling which have positive or negative); over-all adjustment (achieving an overall harmonious balance between demands of various aspects of environment, such as home, health, social, emotional and school of the one hand and cognition on the other);autonomy(a stage of independence and self-determination in thinking);security-insecurity (a high or low sense of safety, confidence, and freedom from fear, apprehension or anxiety particularly with respect to fulfilling the person's present or future needs); self-concept (sum total of the person's attitude and knowledge towards himself and evaluation of his achievements); and intelligence (general mental ability which helps the person in thinking rationally, and in behaving purposefully in his environment).

While, the interpretation of mental health by Das (2008) is "Good mental health can be achieved by following the principle of mental hygiene, which is the science of the investigation and application of those measures that prevent mental disorder. Mental health is a way of living satisfactorily and effectively with other members of the society”.

There have been many studies conducted to access the level of mental health among school teachers in relation to various psychological variables. It is important to emphasize that these different determinants interact with each other in a dynamic way, and that they can work for or against a particular individual's mental health state. Table 1 provides an illustrative set of factors that may threaten or protect mental health. For example, an individual's level of self-worth could be enhanced or diminished depending on social support or economic security at the household level, which in turn might be influenced by the extent of political stability, social justice or economic growth in a country.

\begin{tabular}{|c|c|c|c|}
\hline \multicolumn{4}{|c|}{$\begin{array}{l}\text { Table 1: Mental health determinants } \\
\text { (c.f. Risks to mental health, WHO, 2012) }\end{array}$} \\
\hline Level & Adverse factors & & Protective factors \\
\hline $\begin{array}{l}\text { Individual } \\
\text { attributes }\end{array}$ & $\begin{array}{l}\text { Low self-esteem } \\
\text { Cognitive/emotional } \\
\text { immaturity } \\
\text { Difficulties in } \\
\text { communicating } \\
\text { Medical illness, substance } \\
\text { use }\end{array}$ & $\begin{array}{l}\longleftrightarrow \\
\longleftrightarrow \\
\longleftrightarrow\end{array}$ & $\begin{array}{l}\text { Self-esteem, confidence } \\
\text { Ability to solve problems and } \\
\text { manage stress or adversity } \\
\text { Communication skills } \\
\text { Physical health, fitness }\end{array}$ \\
\hline
\end{tabular}




\begin{tabular}{|c|c|c|c|}
\hline $\begin{array}{l}\text { Social } \\
\text { circumstances }\end{array}$ & $\begin{array}{l}\text { Loneliness, bereavement } \\
\text { Neglect, family conflict } \\
\text { Exposure to violence/abuse } \\
\text { Low income and poverty } \\
\text { Difficulties or failure at } \\
\text { school } \\
\text { Work stress, unemployment }\end{array}$ & $\begin{array}{l}\stackrel{\leftrightarrow}{\longleftrightarrow} \\
\stackrel{\leftrightarrow}{\longleftrightarrow} \\
\stackrel{\leftrightarrow}{\longleftrightarrow}\end{array}$ & $\begin{array}{l}\text { Social support of family \& friends } \\
\text { Good parenting / family interaction } \\
\text { Physical security and safety } \\
\text { Economic security } \\
\text { Scholastic achievement } \\
\text { Satisfaction and success at work }\end{array}$ \\
\hline $\begin{array}{l}\text { Environmental } \\
\text { factors }\end{array}$ & $\begin{array}{l}\text { Poor access to basic } \\
\text { services } \\
\text { Injustice and discrimination } \\
\text { Social and gender } \\
\text { inequalities } \\
\text { Exposure to war or disaster }\end{array}$ & $\begin{array}{l}\longleftrightarrow \\
\longleftrightarrow \\
\longleftrightarrow\end{array}$ & $\begin{array}{l}\text { Equality of access to basic services } \\
\text { Social justice, tolerance, integration } \\
\text { Social and gender equality } \\
\text { Physical security and safety }\end{array}$ \\
\hline
\end{tabular}

Ananda (1989) conducted a study on mental health of schoolteachers using a mental health scale and observed that $59 \%$ of teachers were mentally healthy. The state of working bears no relation to mental health while social values were positively related to mental health of teachers.

Kumar (1992) observed that if a teacher is with bad mental health it not only tends to incapacitate himself for the performance of his multifarious duties in the school but also creates difficulties and problem for his students.

Kaur (2007) investigates occupational stress, mental health and coping resources of high and higher secondary school teachers and their relationship. The results revealed that sometimes teachers feel stressed due to role overload, responsibilities and physical stressors present in school. Whereas, teachers those who are mentally healthy use coping resources to combat the effect of occupational stress. They use recreational activities such as watching T.V., listening music, getting social support from friends to relief from mental tensions, etc. The result also indicated that correlation between occupational stress and mental health is negative. Occupational stress and coping resources also tends to be negative. Correlation between mental health and coping resources is positive and significant.

Srivastava and Khan (2008) conducted a study to know the impact of mental health on the level of burnout of the teachers teaching at different education level. They concluded that teachers with low mental health are more prone to burnouts than the teachers of average and high mental health.

Srivastava(2010) assessed the personality and mental health among primary and secondary teachers. The result indicates that personality types/traits influence the mental health of primary and secondary teachers and extrovert teachers enjoy better mental health as compared to introvert teachers. 
Kale (2011) conducted a study on awareness of mental health among newly admitted B.Ed. Students. The researcher has applied survey method for collecting the data. The results reveal that there is great awareness about the mental health among newly admitted B.Ed students.

Kumar (2013) reported results of t-test reveals that urban elementary school teachers scored higher mean scores on mental health $(\mathrm{t}=-16.06 ; \mathrm{p}<.01)$ whereas, elementary school teachers from rural schools are scored low on mental health. Meaning thereby, awareness of self-mental health would make elementary school teachers' to cope with stressful situation in an enhanced way and are in a better position to perform appraisal of pupils' undesirable behaviour at elementary school level.

In sum a teacher can often create a classroom environment in an image of their own childhood experiences and cultural influences (Kroeger \& Bauer, 2004). This image could mimic how they were taught at school, and in still their own beliefs on how homes and lives are organized, believing that this is the right way and is how will be (Thorsborne \& Vinegrad, 2006). Some of the researchers like Langley (2008) suggested that teachers need to consider there are times when the problem is within themselves and not the child.

\section{OBJECTIVES}

On the basis of provided conceptual description and literature review regarding mental health among school teachers following objectives were proposed for the present study:

1. To assess the mental health among government school teachers.

2. To find out gender differences among school teachers with regard to mental health.

3. To compare mental health level of school teachers posted at urban located schools versus school teachers posted at rural located schools.

\section{Hypotheses:}

1. There would be significant gender differences with regard to mental health.

2. There would be significant differences between school teachers posted at schools located at rural and urban areas.

\section{METHODOLOGY}

\section{Sample}

Random sampling technique has been used for selecting the sample. The investigator selected 100 secondary and higher secondary school teachers within the age range of 35 to 50 yearsfrom various districts of Haryana. For the final testing 100 participants were equally divided into two group's male and female (50 in each group).All the teachers hold at least five years of minimum teaching experience at present posting and living with family members. 
Tools

The following tools were used for the present investigation:

1. MENTAL HEALTH INDEX [MHI-38; Davies, Sherbourne, Peterson, \& Ware (1998)]: All of the $38 \mathrm{MHI}$ items, except two, are scored on a six-point scale (range 1-6). Items 9 and 28 are the exception, each scored on a five-point scale (range 1-5). The precoded values of each item are shown on the copy of the instrument on the preceding pages.

\section{Procedure}

After getting the formal permission from the Principals' of concerned institutions, data was collected. Participants were briefed about the nature and the purpose of the research in order to receive the reliable data. They were assured about the confidentiality of the data. Instructions were given regarding the questionnaires. The scale was filled by the participants, while they were on duty and collected immediately after completion.

\section{Statistical analysis}

Descriptive analysis and t test were used for the assessment of teacher's mental health. The data was analyzed with the help of SPSS-21. Obtained statistical results are given in the section following.

\section{RESULTS \& DISCUSSION}

The results of statistical analysis for the present investigation has been presented with the help of tabulation, show the descriptive statistical values for the said variables. Additionally, gender differences and differences between teachers posted at urban and rural located schools t-test was applied.

Table 1: Shows descriptive statistics for the overall data.

\begin{tabular}{|l|l|l|l|l|l|}
\hline Variable & N & Mean & SD & Skewness & Kurtosis \\
\hline Mental Health & 100 & 99.92 & 38.18 & .266 & -1.051 \\
\hline
\end{tabular}

It is evident from the Table1 that mean values for mental health are falling on the higher side. Which means that majority of government teachers comprises the present sample experience higher mental health associated with their occupational demands.

Table 2: Mental health of male and female school teachers

\begin{tabular}{|l|l|l|l|l|l|}
\hline GENDER & N & Mean & SD & t -value & Level of significance \\
\hline Male & 50 & 108.86 & 39.01 & 2.39 & 0.02 \\
\hline Female & 50 & 90.98 & 35.49 & & \\
\hline
\end{tabular}


Form the Table 2, indicates the difference of mental health between both the groups (male and female). It is evident that mental health of male and female school teachers has significant difference $(\mathrm{t}=2.39 ; \mathrm{p} \leq .02)$. Male experience better mental health as compared to their female counterparts. Reasons may be, single role as a teacher by male teachers whereas females has to maintain personal as well as professional fronts even if commute long distances, men can manage whereas females has to face lots of difficulties.

Table 3: Mental health of rural and urban school teachers

\begin{tabular}{|l|l|l|l|l|l|}
\hline Locality & N & Mean & SD & t- value & Level of Significance \\
\hline Rural & 50 & 79.16 & 33.32 & -6.46 & 0.001 \\
\hline Urban & 50 & 120.68 & 30.91 & & \\
\hline
\end{tabular}

Form the Table 3, it is found that there is significant difference between rural and urban school teachers mental health $(\mathrm{t}=-6.46 ; \mathrm{p} \leq .001)$. Government school teachers posted at urban areas are found high on mental health as compared to those who are posted at rural areas located schools. Reasons may be, better commuting facilities, short distance between school and home, connectivity to district authorities and better life style (facility of parks for walks, medical facilities, better network quality, access to hobby classes for self and children etc.).

In sum, it has been found that the male school teachers' mental health is found to behigher than the female school teachers. Additionally, based on locality the urban school teacher is found to be higher than the female school teachers. Hence, both the hypotheses is accepted.

\section{CONCLUSION}

Mental health is a specialized field of psychiatry and its objective is to safeguard mental health by preventive measures, controlling factors effective on the development of mental diseases, timely diagnosis of mental diseases, prevention from complications due to relapse of mental diseases and the providing a healthy environment as a contributory factor on sound human relationship (Milanifar, 1997). Present study investigates this issue and tries to provide answers for the following question with regard to mental health of school teachers.

Ananda (1989) conducted a study on mental health of school teachers using a mental health scale and observed that fifty nine percent of teachers were mentally healthy. The development of our country is in the hands of the teachers. Good mental health is highly essential for all in general and particularly teachers. Poor mental health of teachers has an adverse effect indirectly as well as sometimes directly on the development of learner's personality. All the school administrators and higher authorities should take keen interest in developing and maintaining positive mental health of teachers and students.

Therefore, it is necessary to establish guidance and counseling cell in all the schools. It will help to solve mental, psychological and health related problems of teachers and students. Mental health promotion related workshops, seminars, groups discussions and conferences should be 
organized at the interschool level then only teachers and students benefited. The teachers' mental health is directly related to the work of classroom. Thus, good mental health of the teacher should as important qualification as academic competence.

\section{REFERENCES}

Anand (1989). Buch, M.B., 1983-88, Fourth Survey of Research In Education, Vol -1. New Delhi: NCERT.

Das, C. (2008). Need for health education in the 21st century with special reference to reproduction health of adolescents. Journal of Community Guidance and Research, 25(2), p-26-32

Kaur, H. (2007). Mental health of Post Graduate Students in relation to their Value-Conflict. M.Ed. Dissertation, Punjab University.

Kornhauser (1965). Quoted in Singh,A.K. and Gupta, A.S. (1983). Mental Health Battery. Ankur Psychological Agency, 22/481, Indira Nagar, Lucknow. p.-3.

Kumar, P. (1992). Mental Health Checklist. National Psychology Corporation, Agra.

Kumar, R. (2013). A study of relationship between teacher's mental health and appraisals of student's undesirable behaviors at elementary level. M.A. Psychology project submitted to IGNOU.

Milanifar, B. (1997). Mental Health, 5th ed, Tehran: Qums Publications.

Moser, K. (1997). Commitment in organizations. Psychologies, 41 (4), 160-170.

Singh, A \&Walia, G. S. (2004). Health and Physical Education. Vinod publications, Ludhiana.

Singh, A. K. \& Gupta, A. S. (1983). Mental Health Battery. Ankur Psychological Agency, 22/481, Indira Nagar, Lucknow. pp.1-11.

Singh, K. P., Chandra, T. \&Parihar, A. J. S. (2011). Advanced Educational Psychology. Meerut: R. Lall Book Depot, pp. 772-774.

Srivastava, D. K. \& Khan, J. A. (2008). Disability Needs Attention Now!.Indian Journal for the Practicing Doctor, 5, 3-4.

Srivastava, S. K. (2003). An assessment of Personality and Mental Health among Primary and Secondary Teachers. Retrieved on (September, 10, 2010) from online Access link http://medind.nic.in/haa/t05/i2/haat05i2p50.pdf

The world health report 2001 - Mental Health: New Understanding, New Hope (PDF). WHO. Retrieved 4 May 2014.

WHO. (2012). Risks to mental health: an overview of vulnerabilities and risk factors. 1-14. 